\title{
Fragmentation of a high speed pulsed jet: thin sheets and their numerical demise
}

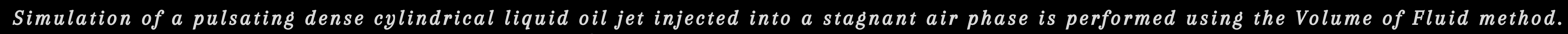
Extremely high refinement (maxlevel 14, $D / \Delta=915$ points per diameter), equivalent to 4400 billion cells on a uniform grid.

$R e=5800, W e=222.2$, density ratio $=25, S t \sim 0.2778$
